\title{
NEONATAL SEPSIS AND MENINGITIS CAUSED BY Neisseria meningitidis: A CASE REPORT
}

\author{
Mário Cícero FALCÃO(1), Samantha Brasil de ANDRADE(2), Maria Esther Jurfest Rivero CECCON(1) \& Flávio Adolfo COSTA VAZ(3)
}

\begin{abstract}
SUMMARY
Objective: To report a full-term newborn infant that developed a sepsis associated to meningitis caused by Neisseria meningitidis serogroup $\mathrm{C}$ on the $14^{\text {th }}$ day of life.

Case description: The patient was a term female infant, born to a mother with Systemic Lupus Erythematosus, with birth weight of 2,610g, Apgar Score 1, 4 and 8, who needed mechanical ventilation for 24 hours. On the $7^{\text {th }}$ day of life, the neonate was discharged from the hospital with good overall condition. On the $15^{\text {th }}$ day of life, the newborn infant presented fever and respiratory failure. The cerebrospinal fluid showed 1042 cells $/ \mathrm{mm}^{3}$, with neutrophilic predominance, protein of $435 \mathrm{mg} / \mathrm{dL}$, and glucose $<10$ $\mathrm{mg} / \mathrm{dL}$. The blood and the cerebrospinal fluid cultures were positive for Neisseria meningitidis serogroup C. The neonate was hospitalized, needing mechanical ventilation and vasoactive drugs, and received 21 days of crystalline penicillin. After hospital discharge, there were no signs of neurological sequels and the infant was able to be breastfed.

The case report presents a unique situation: an uncommon etiology of neonatal meningitis and favorable evolution, despite neurological sequels reported in the literature. This report emphasizes the need to prevent the premature exposure of newborn infants to pathological agents, especially if they presented birth injuries and/or are preterm, due to their lack of immunological capacity.
\end{abstract}

KEYWORDS: Meningitis; Sepsis; Neisseria meningitidis; Infant; Newborn.

\section{INTRODUCTION}

Although Neisseria meningitidis, Haemophilus influenzae, and Streptococcus pneumoniae are responsible for the majority of the cases of meningitis in children, these microorganisms are relatively uncommonly found in neonatal meningitis ${ }^{9}$. Data from the Centers for Disease Control and Prevention (CDC-USA) point to a prevalence of the neonatal meningitis caused by Neisseria meningitidis of about 2/ 10,000 newborn infants ${ }^{12,17}$. This survey shows that amongst the neonatal meningitis cases, only $0.54 \%$ has a meningococcal etiology. More current American data from the "Bacterial Core Surveillance Program", disclose an annual incidence of 9/100,000 newborn infants ${ }^{15}$.

Thus, Neisseria meningitidis is one of the main causes of meningitis in children and adolescents and is associated with a high morbidity and mortality. However, meningococcal infection is rare in the neonatal period $^{7,10}$, possibly due to the passage of passive protective antibodies through the placenta. This clinical case reports a term newborn infant that remained in the Neonatal Intensive Care Unit (NICU) for seven days due to perinatal asphyxia, being discharged in good overall condition and who returned on $14^{\text {th }}$ day of life with a history of fever and respiratory failure, evolving to septic shock. The blood and the cerebrospinal fluid cultures were positive for Neisseria meningitidis, which was later classified as being from serogroup C.

\section{CASE REPORT}

The patient is a female term newborn infant, with gestational age of 39 weeks, birth weight of $2,610 \mathrm{~g}$, born through Caesarean section delivery, Apgar score of 1,4 and 8 , at the $1^{\text {st }}, 5^{\text {th }}$, and $10^{\text {th }}$, minutes of live, respectively. The neonate was classified as being small for gestational age, classified under the $10^{\text {th }}$ percentile of the Curve of Intrauterine Growth adopted by the Unit.

The mother, who had Systemic Lupus Erythematosus and used corticosteroid drugs at immunosuppression doses, was followed in a High Risk Prenatal Clinic and was hospitalized at the $39^{\text {th }}$ week of gestation to deliver, as she presented intrauterine growth restriction and alteration of fetal vitality, detected by ultrasonography.

The newborn infant received resuscitation procedures, including intubation; after that, the neonate was transferred to the NICU where she received mechanical ventilation for 24 hours, without the need for vasoactive drug use.

The infant recovered, mechanical ventilation was withdrawn and

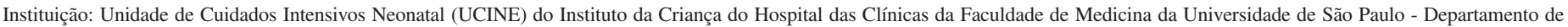
Pediatria da Faculdade de Medicina da Universidade de São Paulo, São Paulo, SP, Brasil.

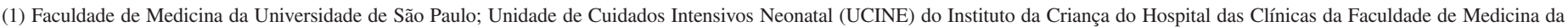
Universidade de São Paulo, SP, Brasil.

(2) Unidade de Infectologia do Instituto da Criança do Hospital das Clínicas da Faculdade de Medicina da Universidade de São Paulo, SP, Brasil.

(3) Departamento de Pediatria da Faculdade de Medicina da Universidade de São Paulo, SP, Brasil.

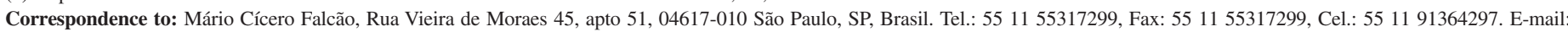
profmariofalcao@yahoo.com.br 
supplied oxygen was suspended after 72 hours of life. After that, the neonate started to be breastfed, with good acceptance. The hospital discharge occurred on the $7^{\text {th }}$ day of life; the infant weighed $2,520 \mathrm{~g}$, and was in good clinical conditions. On the $15^{\text {th }}$ day of life, the infant's mother sought the Pediatric Emergency Room from Instituto da Criança do Hospital das Clínicas da Faculdade de Medicina da Universidade de São Paulo (ICr-HC-FMUSP), reporting a history of fever $\left(39^{\circ} \mathrm{C}\right)$ and respiratory failure. In addition to the fever, the newborn infant presented cyanosis, tachycardia (180/minute) and respiratory failure (83/minute); she was then placed on oxygen inhalation and the healthcare team collected material for infection screening (whole blood count, blood culture, urine culture, cerebrospinal fluid, C-reactive protein and X-ray). Hemodynamic support and antibiotics were given to the newborn infant (Vancomycin and Cefepime), as the first clinical suspicion was delayed sepsis of nosocomial origin. There were no signals of metabolic acidosis, as well as no electrolytic alterations and the blood glucose was $120 \mathrm{mg} / \mathrm{dL}$. The cerebrospinal fluid showed 1042 cells $/ \mathrm{mm}^{3}$ (21\% of lymphocytes, $12 \%$ of monocytes and $62 \%$ of neutrophils), protein level of $435 \mathrm{mg} / \mathrm{dL}$, and glucose $<10 \mathrm{mg} / \mathrm{dL}$; the bacterioscopy showed the presence of numerous Gram-negative diplococcus, and polymorphonuclear leukocytes. The whole blood count showed: hematocrit of $40 \%$, hemoglobin of $12.7 \mathrm{~g} / \mathrm{dL}, 6,600 / \mathrm{mm}^{3}$ leukocytes (5\% of myelocytes, $5 \%$ of metamyelocytes, $22 \%$ of rod neutrophils, $13 \%$ of segmented neutrophils, 32\% of lymphocytes, $8 \%$ of monocytes and $1 \%$ of eosinophils), and platelet count of 38,700/ $\mathrm{mm}^{3}$. The C-reactive protein was $149 \mathrm{mg} / \mathrm{dL}$. The newborn was transferred to the NICU, with a diagnosis of sepsis and neonatal meningitis, where she was placed under respiratory therapy and contact isolation.

The neonate presented worsening of the peripheral perfusion and reduction in blood pressure levels, and worsening of the respiratory failure. Intubation was necessary as well ventilatory support and vasoactive drugs. After 24 hours, the blood and the cerebrospinal fluid cultures showed to be positive for Neisseria meningitidis serogroup C, and the infant was started on $400,000 \mathrm{IU} / \mathrm{kg}$ of crystalline penicillin. Parenteral nutrition was started through a central catheter. After the change of antibiotic therapy, the whole blood count showed: hematocrit of $34.5 \%$, hemoglobin of $10.6 \mathrm{~g} / \mathrm{dL}$, platelet count of $41,600 / \mathrm{mm}^{3}$ and leukocytes of $14,300 / \mathrm{mm}^{3}$ (3\% of rod neutrophils, $45 \%$ of segmented neutrophils, $36 \%$ of lymphocytes, $11 \%$ of monocytes and $5 \%$ of eosinophils); C-reactive protein increased to $178 \mathrm{mg} / \mathrm{dL}$. As the newborn infant remained stable, without acidosis and did not need increase in the mechanical ventilation parameters, the antibiotic was maintained. On $4^{\text {th }}$ day of hospitalization, after 48 hours of crystalline penicillin, the whole blood count showed nearly normal levels, with only mild anemia; platelet count was normal and the C-reactive protein reflected an important reduction $(58 \mathrm{mg} / \mathrm{dL})$. However, the cerebrospinal fluid still showed to be altered with 423 cells $/ \mathrm{mm}^{3}$ (11\% of lymphocytes, $35 \%$ of monocytes and $54 \%$ of neutrophils), and glucose and protein levels were $21 \mathrm{mg} / \mathrm{dL}$, and $219 \mathrm{mg} / \mathrm{dL}$, respectively; the cerebrospinal fluid and blood cultures were negative by then.

The newborn evolved with clinical improvement, with withdrawal of the vasoactive drugs and the ventilatory support. On the $5^{\text {th }}$ day of hospitalization maternal milk was reinstated, with fast progression and on the $7^{\text {th }}$ day the isolation was suspended, although the cerebrospinal fluid control still show high cellularity $\left(105 \mathrm{cell} / \mathrm{mm}^{3}-55 \%\right.$ of lymphocytes, $5 \%$ of monocytes, and $39 \%$ of neutrophils), and high protein content $(257 \mathrm{mg} / \mathrm{dL})$, although with clear improvement in relation to the previous days. Despite the clinical and laboratory improvement, the staff decided to maintain the antibiotic therapy for 21 days, following the protocol for neonatal meningitis treatment.

The cranial ultrasonography and computed tomographic, and the electroencephalogram were normal; the C-reactive protein levels after 10 days of crystalline penicillin was $1.47 \mathrm{mg} / \mathrm{dL}$, and $0.43 \mathrm{mg} / \mathrm{dL}$ at the hospital discharge. The whole blood count still showed moderate anemia ( $8.8 \mathrm{~g} / \mathrm{dL}$ of hemoglobin) and the control of the cerebrospinal fluid, at this occasion, revealed to be normal. The newborn infant had evolved well and was discharged receiving exclusively breast milk, with additional vitamins, A and D.

\section{EPIDEMIOLOGICAL HISTORY}

After the isolation of the agent (Neisseria meningitidis), the team of the Center of Epidemiological Monitoring of the Health Secretary of São Paulo interviewed the family in order to verify who had been infected. However, the contaminating source was not found among the family members or hospital staff who had had contact with the child.

The mother's and sister's child received chemotherapy with Rifampin; the sister was younger than five years and the mother was considered immunosuppressed, as she was receiving corticosteroids due to Systemic Lupus Erythematosus. The parents reported to have received many visits to the newborn at home, as the birth was coincident with the end-of-the-year holiday season.

Many visitors could not be tested, as they had already returned to their home towns. The persons who were tested did not show any evidence of positive results. The antibiotic therapy was indicated to all children under five years old who had had contact with the newborn infant.

\section{DISCUSSION}

Neisseria meningitidis is one of the main causes of meningitis in children and adolescents, but it is rare in the neonatal period ${ }^{6,13}$. The bibliographical survey showed that there have been around 45 cases described in literature similar to this one, with no previous Brazilian reports. Low frequency of this infection in the neonatal period is probably related to transfer of maternal protective antibodies. Approximately $50 \%$ of the newborns have protective antibodies against meningococcal bacteria at birth, and these antibodies decline from the $6^{\text {th }}$ month of life on and disappear around the $18^{\text {th }}$ to $24^{\text {th }}$ month. In the described case, the mother had an autoimmune disease (Systemic Lupus Erythematosus) and she used corticosteroids at immunosuppression doses. Probably, this therapeutic action modified the cellular and humoral immunity, diminishing the transfer of antibodies and increasing the susceptibility of the newborn infant.

In many persons, Neisseria meningitidis colonizes the pharynx without causing infection and illness; therefore, a few cases evolve to the invasive form. Some factors can be determinant for the transition from the non-symptomatic carrier state to the invasive illness. Usually, the meningococcal infection occurs in the recently colonized individuals 
and those who do not have protective antibodies for the agent; therefore, in these cases, the meningococcal infection agent is capable of crossing the epithelial membrane of the respiratory system, thus invading the blood. Moreover, it is possible that local trauma to the nasopharynx can allow invasive illnesses to occur. The newborn in this case was submitted to intubation for ventilatory support. This procedure can result in injury of the respiratory tract and it would have been the source of contamination by Neisseria meningitidis. Furthermore, Neisseria meningitidis can colonize the maternal genital tract, correlating with inflammatory pelvic disease ${ }^{11,16}$, concomitant with intrauterine infection ${ }^{8}$. In the majority of the reported cases, the initial symptoms of neonatal meningococcemia are undefined, appearing after fever and irritability that are soon followed by shock and multiple-organ failure, which can be fatal in few hours ${ }^{4}$. Although there is a description of the association between purpurae and meningococcal infection in a 15 day-old newborn, purpurae is uncommon in the neonatal period. They are manifestations of vascular inflammation and antigen-antibody reactions, and newborn infants are not able to produce these reactions, because of their immunological immaturity ${ }^{14}$. The bleeding described in some cases in the neonatal period can be secondary to the septic shock and disseminated intravascular coagulation.

In this case, the mother sought medical care at the first manifestations of the disease (fever and respiratory failure); as the child had been discharged less then one week before from a Neonatal Intensive Care Unit, the medical emergency team hypothesized a possible nosocomial infection, recommended hospitalization and early large-spectrum antibiotic therapy, which probably contributed for the good evolution of this case.

Despite the favorable evolution of this case, the literature shows, in the few existing reports, a high probability of neurological sequelae, and also the risk of neonatal death, regardless of the correct treatment $t^{1,3,5}$. Moreover, there have been reports of cerebral abscesses caused by meningococcal infection in the neonatal period ${ }^{2}$.

Regarding the epidemiology, the newborn was under respiratory therapy and contact isolation since her admission at the Neonatal Intensive Care Unit, thus not compromising other hospitalized infants; the medical team that entered in contact with the child in the Emergency Room also received chemoprophylaxis. The newborn's relatives who were tested did not show to be asymptomatic carriers, but the newborn was visited by many other persons who were not tested. These persons visited the family during the period of year-end holiday season.

The description of this uncommon etiology of sepsis and meningitis in the neonatal period aims at improving the advice given at the discharge from the Nursery, in order to prevent the premature exposure of the newborn infants, especially if they have experienced birth injuries or if they are premature, due to the immaturity of the immunological system.

\section{RESUMO}

\section{Sepse e meningite neonatal por Neisseria meningitidis: relato de caso}

Objetivo: Relatar o caso de um recém-nascido de termo que apresentou no $14^{\circ}$ dia de vida sepse associada à meningite, cujo agente etiológico foi a Neisseria meningitidis sorotipo C.

Descrição do caso: recém-nascido de termo, cuja mãe é portadora de lupus eritematoso sistêmico, feminino, peso de nascimento de $2610 \mathrm{~g}$, Escala de Apgar 1, 4 e 8, sendo intubado e ventilado por 24 horas. Recebeu alta no $7^{\circ}$ dia de vida em boas condições. No $15^{\circ}$ dia de vida apresentou febre e desconforto respiratório. O líquido cefalorraquidiano mostrou 1042 células $/ \mathrm{mm}^{3}$, com predomínio de neutrófilos, proteinorraquia de $435 \mathrm{mg} / \mathrm{dL}$ e glicorraquia < $10 \mathrm{mg} / \mathrm{dL}$; a bacterioscopia revelou a presença de diplococos. Foi internado na Terapia Intensiva Neonatal, necessitou de ventilação mecânica e de drogas vasoativas. A hemocultura e a cultura do líquido cefalorraquidiano foram positivas para Neisseria meningitidis $\mathrm{C}$. $\mathrm{O}$ recém-nascido foi tratado por 21 dias com penicilina cristalina. Recebeu alta hospitalar em boas condições, em aleitamento materno exclusivo e sem seqüelas neurológicas.

O caso descrito apresenta como peculiaridades: etiologia incomum de meningite neonatal e evolução favorável, apesar dos relatos em literatura mostrarem seqüelas neurológicas. Destaca-se ainda, a necessidade de enfatizar a não exposição precoce do recém-nascido, especialmente se tiver tido agravos ao nascimento ou for prematuro, devido à sua inexperiência imunológica.

\section{REFERENCES}

1. BHUTTA, Z.A.; KHAN, I.A. \& AGHA, Z. - Fatal intrauterine meningococcal infection Pediat. infect. Dis. J., 10: 868-869, 1991.

2. CHUGH, K.; BHALLA, C.K. \& JOSHI, K.K. - Meningococcal abscess and meningitis in a neonate. Pediat. infect. Dis. J., 7: 136-137, 1988.

3. CIGNI, A.; COSSELLU, S.; PORCU, A. \& PIGA, S. - Meningococcal osteomyelitis in a premature infant. Ann. ital. Med. intern., 19: 280-282, 2004.

4. CLEGG, H.W.; TODRES, I.D.; MOYLAN, F.M.; KEIM, D.E. \& SHANNON, D.C. Fulminant neonatal meningococcemia. Amer. J. Dis. Child., 134: 354-355, 1980.

5. ELLIS, M; WEINDLING, A.M.; DAVIDSON, D.C.; HO, N. \& DAMJANOVIC, V. Neonatal meningococcal conjunctivitis associated with meningococcal meningitis. Arch. Dis. Childh., 67: 1219-1220, 1992.

6. EMBREE, J.; LAW, B.J.; WILLIAMS, T. \& EDYE-MAZOWITA, G. - Early onset neonatal sepsis due to Neisseria meningitidis W135. Pediat. infect. Dis. J., 6: 299300, 1987.

7. FALERO-GALLEGO, M.P.; ARROYOS-PLANA, A.; SANTILLANA-FERRER, L. et al. - Late neonatal sepsis with meningitis due to meningococcus serogroup C. An. esp. Pediat., 50: 639-640, 1999.

8. JONES, R.N.; STEPACK, J. \& EADES, A. - Fatal neonatal meningococcal meningitis. Association with maternal cervical-vaginal colonization. J. Amer. med. Ass., 236: 2652-2653, 1976

9. KEIN, J.O. \& MARCY, S.M. - Bacterial sepsis and meningitis. In: REMINGTON, J.S. \& KLEIN, J.O., ed. Infectious diseases of the fetus and newborn. 4 ed. Philadelphia, W.B. Saunders, 1995. p. 835-890.

10. LO, W.T.; YUH, T.S.; WANG, C.C. \& CHU, M.L. - Early onset neonatal infection with Neisseria meningitidis serogroup C: case report and literature review. Europ. J. Pediat., 162: 785-787, 2003

11. MANGINELLO, F.P.; PASCALE, J.A.; WOLFSDORF, J. \& KLEIN, G.M. - Neonatal meningococcal meningitis and meningococcemia. Amer. J. Dis. Child., 133: 651652, 1979. 
FALCÃO, M.C.; ANDRADE, S.B.; CECCON, M.E.J.R. \& COSTA VAZ, F.A. - Neonatal sepsis and meningitis caused by Neisseria meningitidis: a case report. Rev. Inst. Med. trop. S. Paulo, 49(3): 191-194, 2007.

12. PINNER, R.W.; GELLIN, B.G.; BIBB, W.F. et al. - Meningococcal disease in the United States, 1986. Meningococcal Disease Study Group. J. infect. Dis., 164: 368-374, 1991.

13. SCHABERG, M.J. - Neonatal meningococcal meningitis. J. Amer. med. Ass., 237: 2381, 1977.

14. SELANDER, B.; SCHLIAMSER, S.; SCHALEN, C. et al. - A premature infant with fulminant meningococcal septicaemia. Scand. J. infect. Dis., 35: 345-348, 2003.

15. SHEPARD, C.W.; ROSENSTEIN, N.E.; FISCHER, M. \& Active Bacterial Core Surveillance Team - Neonatal meningococcal disease in the United States, 1990 to 1999. Pediat. infect. Dis. J., 22: 418-422, 2003.
16. SUNDERLAND, W.A.; HARRIS, H.H.; SPENCE, D.A. \& LAWSON, W.A. Meningococcemia in a newborn infant whose mother had meningococcal vaginitis. J. Pediat., 81: 856, 1972

17. WENGER, J.D.; HIGHTOWER, A.W.; FACKLAN, R.R.; GAVENTA, S. \& BROOME C.V. - Bacterial meningitis in the United States, 1986: report of a multistate surveillance study. The Bacterial Meningitis Study Group. J. infect. Dis., 162: 13161323, 1990.

Received: 22 May 2006

Accepted: 20 October 2006 